\title{
Taeniasis in non-descript dogs in Ngorongoro, Tanzania: Prevalence and predisposing factors
}

\begin{tabular}{|c|c|}
\hline $\begin{array}{l}\text { Authors: } \\
\text { Emmanuel S. } \\
\text { Miran B. Mira } \\
\text { Ayubu A. Kasu } \\
\text { Jahashi Nzalav }\end{array}$ & $\begin{array}{l}\text { wai } \\
\text { na }^{2} \\
\mathrm{ku}^{3} \\
\text { vahe }^{3}\end{array}$ \\
\hline $\begin{array}{l}\text { Affiliations: } \\
{ }^{1} \text { Ministry of Li } \\
\text { Fisheries Deve } \\
\text { Dar-es-Salaam }\end{array}$ & $\begin{array}{l}\text { Jestock and } \\
\text { lopment, } \\
\text {, Tanzania }\end{array}$ \\
\hline $\begin{array}{l}{ }^{2} \text { Livestock Dep } \\
\text { Ngorongoro D } \\
\text { Tanzania }\end{array}$ & $\begin{array}{l}\text { artment, } \\
\text { istrict Council, }\end{array}$ \\
\hline $\begin{array}{l}{ }^{3} \text { Department } \\
\text { and Parasitolo } \\
\text { University of } \\
\text { Tanzania }\end{array}$ & $\begin{array}{l}\text { f Microbiology } \\
\text { gy, Sokoine } \\
\text { griculture, }\end{array}$ \\
\hline $\begin{array}{l}\text { Correspondin } \\
\text { Emmanuel Sw } \\
\text { esswai@gmail }\end{array}$ & $\begin{array}{l}\text { author: } \\
\text { ai, } \\
\text {.com }\end{array}$ \\
\hline $\begin{array}{l}\text { Dates: } \\
\text { Received: } 16 \mathrm{~J} \\
\text { Accepted: } 08 \\
\text { Published: } 24\end{array}$ & $\begin{array}{l}\text { uly } 2015 \\
\text { May } 2015 \\
\text { May } 2016\end{array}$ \\
\hline $\begin{array}{l}\text { How to cite th } \\
\text { Swai, E.S., Mir } \\
\text { Kasuku, A.A. \& } \\
\text { 2016, 'Taenias } \\
\text { descript dogs } \\
\text { Tanzania: Prev } \\
\text { predisposing f } \\
\text { Onderstepoor } \\
\text { Veterinary Res } \\
\text { a1013. http:// } \\
\text { org/10.4102/c }\end{array}$ & $\begin{array}{l}\text { is article: } \\
\text { an, M.B., } \\
\text { Nzalawahe, J., } \\
\text { is in non- } \\
\text { n Ngorongoro, } \\
\text { alence and } \\
\text { actors', } \\
\text { Journal of } \\
\text { earch } 83(1) \text {, } \\
\text { dx.doi. } \\
\text { jvr.v83i1.1013 }\end{array}$ \\
\hline $\begin{array}{l}\text { Copyright: } \\
\text { (C) 2016. The A } \\
\text { Licensee: AOS } \\
\text { is licensed unc } \\
\text { Creative Comr } \\
\text { Attribution Lic }\end{array}$ & $\begin{array}{l}\text { uthors. } \\
\text { S. This work } \\
\text { ler the } \\
\text { nons } \\
\text { ense. }\end{array}$ \\
\hline Read online: & \\
\hline 口ista & $\begin{array}{l}\text { Scan this QR } \\
\text { code with your } \\
\text { smart phone or } \\
\text { mobile device } \\
\text { to read online. }\end{array}$ \\
\hline
\end{tabular}

The prevalence of taeniasis was determined during the period January to April 2013 in a cross-sectional study of non-descript domestic dogs from the livestock-wildlife ecosystem of Ngorongoro, Tanzania. Taeniid eggs were determined by screening faecal samples using the formalin-ether sedimentation technique. Predisposing factors for dog infection were assessed in relation to demographic, husbandry and management data. Of the 205 faecal samples screened, $150(73.2 \%)$ were positive for taeniid eggs. The prevalence of dogs harbouring taeniid eggs was $80 \%, 30.2 \%$ and $75.3 \%$ in the less than 1 year, $1-3$ years and greater than 3 years of age groups, respectively. Age group and sex prevalence in dogs did not differ significantly $(P>0.05)$, although the females showed a marginally higher prevalence $(73.8 \%)$ in comparison to the males $(72.7 \%)$. Taeniid eggs were significantly more likely to be found in the faeces of dogs located in Waso (80.6\%) and Endulen (75\%) than in Malambo $(63.2 \%, P<0.05)$. The study revealed that dogs owned and raised by agro-pastoralists were at a lower risk of acquiring Taenia spp. infection $(P=0.001)$ than those that were raised by pastoralists. The majority of $\operatorname{dog}$ owners were not aware of the predisposing factors and the mode of transmission of taeniids. Dogs were frequently fed on viscera, trimmings and the heads of slaughtered animals, and they were not treated for parasitic infections. The findings of this study indicate that taeniasis is prevalent among non-descript dogs in Ngorongoro, underscoring the need for further research and active surveillance to better understand the transmission cycle of Taenia spp. in a wider geographical area in Tanzania.

\section{Introduction}

Dogs have been reported to harbour a variety of gastro-intestinal parasites, some of which are of zoonotic importance (Craig \& Macpherson 2000). The impact of infection is greater in sub-Saharan Africa because of the availability of a wide range of agro-ecological factors suitable for diversified hosts and parasite species (Folaranmi et al. 1984; Nonaka et al. 2011; Schandevyl, Mbundu \& Sumbu 1987). Internal parasitism in domestic dogs (Canis familiaris) may result in loss of appetite and poor feed-conversion efficiency and predispose them to other pathogens or even death (Traub et al. 2005). The effects arising from the massive and sub-clinical infections include growth retardation, reduced weight gains and general ill-health (Soulsby 1982).

Taenia multiceps (Leske 1780) (syn. Multiceps multiceps), Taenia hydatigena and Echinococcus granulosus are worldwide cestode helminths that inhabit the small intestine of domestic dogs, wild dogs (Lycaon pictus), hyaenas (Crocuta crocuta), foxes (Vulpes spp.), coyotes (Canis latrans) and jackals (Canis mesomelas, Canis aureus, Canis aductus) (Scala et al. 2007). The definitive hosts for these cestode helminth species are members of the family Canidae. Many animals may serve as intermediate hosts; these include rodents, rabbits, horses, cattle, sheep and goats. The intermediate host becomes infected by ingesting proglottids or eggs passed in the faeces of the dog or wild carnivore in pastures or feeding areas. The definitive host becomes infected by ingesting the tissue of an infected intermediate host containing the metacestodes or larval stage of these worm species. Humans can also be affected by the intermediate host containing the larval stage of T. multiceps (Coenurus cerebralis), T. hydatigena (Cysticercus tenuicollis) and E. granulosus (cystic echinococcosis) (Sharma \& Chauhan 2006). In the recent past, cases of coenurosis, hydatidosis and cysticercosis have been reported to occur in domestic small ruminants (sheep and goats) in various villages of Ngorongoro where the current study was undertaken (Ernest et al. 2009; Miran et al. 2015).

Surveys targeting helminth infections in dogs have been performed previously in some urban settings in Tanzania, but unfortunately no studies have ever been conducted in an agropastoral or pastoral setting where a considerable number of non-descript dogs can be found (Makene et al. 
1996; Muhairwa, Nonga \& Kusiluka 2008; Swai et al. 2010). Owing to the paucity of data on Taenia infections in dogs in rural areas, the present study was designed and implemented to estimate the prevalence of Taenia spp. infestation in dogs in Ngorongoro district, Tanzania. The presence of cestodes was confirmed by coprological examination, with the aim of generating baseline data and establishing the potential role of these parasites in causing coenurosis, cysticercosis and hydatidosis, often reported in sheep and goats in the study area.

\section{Material and methods Study area}

This study was conducted in Ngorongoro, the largest of the seven districts of Arusha region, northern Tanzania. The district lies between longitude $35^{\prime} 30^{\circ}$ and $36^{\prime} 23^{\circ} \mathrm{E}$ and latitude $02^{\prime} 45^{\circ}$ and $4^{\prime} 0^{\circ} \mathrm{S}$ and covers an area of $14036 \mathrm{~km}^{2}$ (Figure 1). Geographically, the district is bordered by Kenya to the north, Serengeti National Park to the west, Longido and Monduli districts to the east and Karatu District to the south. Administratively, it is divided into 3 divisions, 21 wards and 43 registered villages and sub-villages. Currently the human population is estimated at 174278 , with a growth rate of $2.9 \%$ as opposed to the national growth rate of $3.0 \%$ per annum (URT 2012). The study sites were selected in collaboration with the government livestock extension and administration officers. The sites, commonly referred to as villages or wards, were selected on the basis of the geographical location (one from each of the three existing administrative divisions) and the presence of a high concentration of dogs and also of a slaughter slab where the slaughter of sheep and goats frequently takes place.

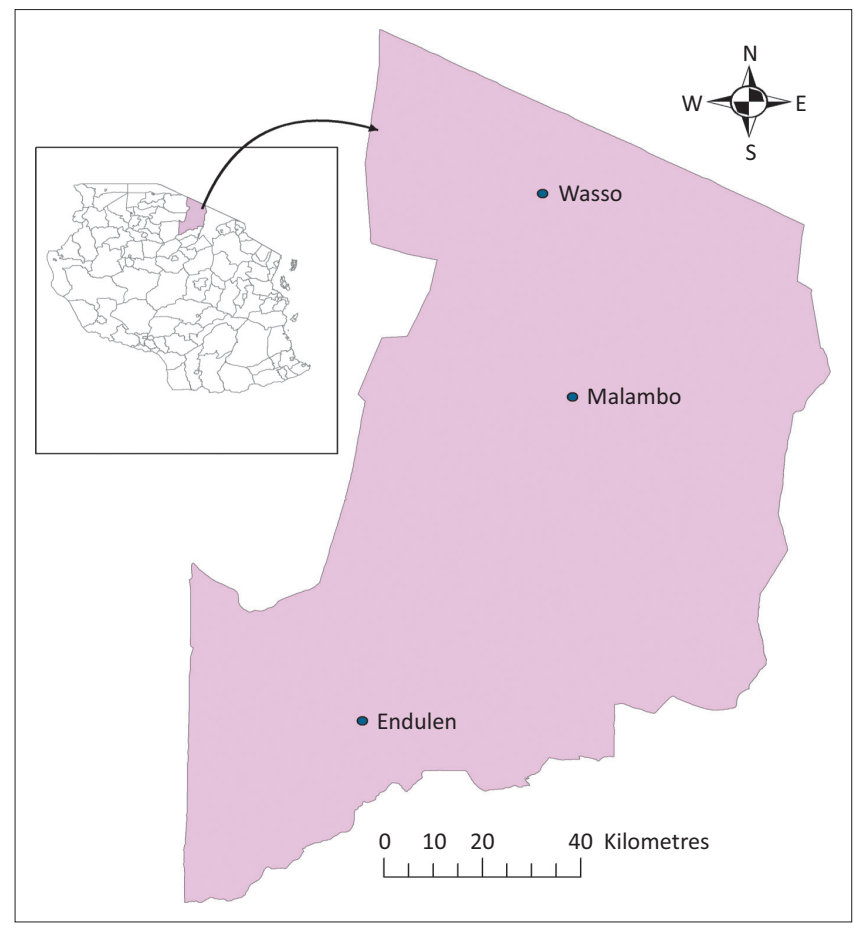

FIGURE 1: Map of Ngorongoro district showing the study villages. The insert is a map of Tanzania.
The selected villages were Endulen, Malambo and Wasso. The study was conducted from January to April 2013.

\section{Study design and sample size}

A cross-sectional study design was adopted and dogs selected for the study were examined and sampled once. Sample size estimation was based on a sampling frame of 2063 dogs distributed across the three selected villages using the formula developed by Martin, Meek and Willeberg (1987):

$n=\frac{Z^{2} p(1-p)}{d^{2}}$

where: $n=$ required sample size; $Z=Z$-value for a given confidence level $(95 \%=1.96) ; d^{2}=$ allowable error $(0.05)$ and $p=$ known or estimated prevalence.

The estimated prevalence was $15 \%$ based on the previous studies in Tanzania (Ernest et al. 2009). Therefore, the calculated sample size was $1.96^{2} \times 0.15 \times 0.85 / 0.05^{2}=196$. However, the practical working sample was raised to 205.

\section{Data collection}

The breeds of dog kept were not known to most of the participating owners and therefore they were classified as non-descript. Data on the dogs' demographic characteristics (age, sex, location) and history of deworming were collected. The ages of the examined dogs were stratified into four agecategories ( $<1$ yrs; $1-2$ yrs; $>2-<3$ yrs and $>3$ yrs). Additional information pertaining to dog husbandry practices was sought by individual questionnaires administered to 121 livestock keepers who were also dog owners. At least 40 interviews were carried out per village. The selection criteria of an interviewee depended on convenience and/or owning $\operatorname{dog}(\mathrm{s})$. The information sought included disposal procedures of offal and/or infected brains condemned by the local meat inspector. These were categorised as (1) raw brain thrown to dogs, (2) thrown into the bush, (3) buried and fed dogs cooked brain from dead or slaughtered animals. Variables investigated included level of worm control practices, dog access to infected condemned offal and to raw brains and other trimmings thrown into the bush; and farming system where dog owners reside (agropastoral or pastoral).

\section{Faecal sample collection and processing}

Faecal samples from 205 domestic dogs (one sample per animal) from the villages where slaughter slabs are located (Wasso - highland, Endulen - medium and Malambo lowland) were collected for laboratory analysis. Faecal samples were collected per rectum using fingers in glove, stored tightly closed, labelled and kept in a coolbox packed with an ice bag before transportation to the Tanzania Wildlife Research Institute's (TAWIRI) Serengeti laboratory, where they were immediately examined or stored refrigerated (at $4{ }^{\circ} \mathrm{C}$ ) for a maximum of one day before processing. Faecal samples were screened for the presence of taeniid eggs. 


\section{Procedure or protocol}

Faecal samples were analysed and interpreted using the formalin-ether sedimentation technique for fresh material (Ash \& Orihel 1987). Briefly, approximately $1.0 \mathrm{~g}-1.5 \mathrm{~g}$ of fresh faecal material was suspended in $10 \mathrm{~mL} 10 \%$ formalin in a $50 \mathrm{~mL}$ cup. The suspension was strained directly into a $15 \mathrm{~mL}$ conical centrifuge tube through two layers of wet gauze; the tube was filled almost to the brim with $0.85 \%$ saline solution and spun at $4000 \times \mathrm{g}$ for two minutes. In cases where the supernatant was still cloudy, it was discarded: the sediment was re-suspended and centrifuged again at $4000 \times \mathrm{g}$ using $0.85 \%$ saline solution. The supernatant was then discarded and the sediment re-suspended in $10 \%$ formalin by sharply flicking the bottom of the tube and more formalin was added to bring the total volume of the suspension to $10 \mathrm{~mL}$. This was followed by adding $3 \mathrm{~mL}$ ether and the solution was shaken vigorously for about 3 seconds and then centrifuged at $5000 \times \mathrm{g}$ for 3 minutes.

The outcome formed four layers, namely, ether, debris that adheres to the wall of the tube, formalin and sediment layers. An applicator stick was inserted to ring and loosen the plug of debris and the three top layers were decanted and discarded. By using a glass pipette, a drop of saline was added and mixed with the sediment. Unstained wet mounts were prepared for examination for each sample and screened using a light microscope. The results were expressed either as positive or negative after microscopic examination based on the presence or absence of taeniid eggs.

\section{Data analysis}

Data were coded and entered in a Microsoft Office Excel spreadsheet and analysed using Epi Info 7 software. Descriptive statistics were generated and presented as tables. The prevalence $(\mathrm{P})$ of dogs harbouring taeniid egg(s) was calculated using the following formula:

$p(\%)=\left(\frac{n}{N}\right) \times 100$

where $n$ is the number of dogs diagnosed as having taeniid eggs at that point in time and $N$ is the number of dogs at risk (examined) at that point in time (Thrusfield 2005).
Associations between parasitism and categorical (host and management) factors were compared using the Chi-square test for independence. Fisher's exact test was used when the numbers within categories were too small for the Chi-square test. In all the analyses, a value of $P<0.05$ was considered significant.

\section{Ethical issues}

Permission to carry out this study was granted by the Executive Director of Ngorongoro District and the research ethical committee of Sokoine University of Agriculture. Verbal consent was obtained from each participating farmer after explaining the purpose and importance of the study prior to starting the data collection. The operating procedures regarding the safety of the researchers, community and environment were strictly adhered to at all stages of sample collection, storage, transportation and processing.

\section{Results \\ Descriptive statistics}

Overall, 205 apparently healthy dogs belonging to 72 farmers were presented and faecal samples collected. Of the 205 dogs examined, 121 (59.1\%) were males and 49 (40.9\%) were females. Some male dogs $(n=16 / 93 ; 17.9 \%)$, mostly from the agro-pastoralist community, were reported to have been dewormed one year prior to the initiation of this study. The breed of dogs examined was defined as non-descript.

\section{Prevalence of taeniid eggs}

Out of a total of 205, 150 (73.2\%) were diagnosed as harbouring taeniid eggs at varying intensities. The proportions of dogs in each category and the mean faecal prevalence of taeniid eggs of each variable investigated during the study $(n=205)$ are given in Table 1.

\section{Factors associated with prevalence of taeniid egg infection}

The factors influencing the prevalence of taeniid infection are given in Table 1. Host age was not found to be a significant factor with respect to the prevalence of taeniid eggs $(p>0.05)$, although eggs were detected more frequently in the young

TABLE 1: Proportions of dogs and prevalence of Taenia spp. infection in each category of each variable investigated during the study $(n=205)$.

\begin{tabular}{|c|c|c|c|c|c|c|}
\hline Variable & Category & Number examined & Percentage (\%) & Prevalence $(\%)$ & $\chi^{2}$ & $P$-value \\
\hline \multirow[t]{2}{*}{ Sex } & Females & 84 & 40.90 & $62(73.8)$ & 0.86 & 0.0296 \\
\hline & Male & 121 & 59.10 & $88(72.7)$ & & \\
\hline \multirow[t]{4}{*}{ Age } & $<1 \mathrm{yr}$ & 30 & 15.40 & $24(80.0)$ & 3.70 & 0.2900 \\
\hline & $1-2$ yrs & 66 & 33.80 & $48(72.7)$ & & \\
\hline & $>2-3$ yrs & 24 & 12.30 & $14(58.3)$ & & \\
\hline & $>3 \mathrm{yrs}$ & 85 & 43.60 & $64(75.3)$ & & \\
\hline \multirow[t]{3}{*}{ Village } & Endulen & 36 & 17.60 & $27(75.0)$ & 6.59 & 0.0370 \\
\hline & Malambo & 76 & 37.10 & $48(63.2)$ & & \\
\hline & Waso & 93 & 45.40 & $75(80.6)$ & & \\
\hline \multirow[t]{2}{*}{ Owner production system } & Agropastoral & 93 & 45.40 & $37(39.8)$ & 14.67 & 0.000128 \\
\hline & Pastoral & 112 & 54.60 & $74(66.1)$ & & \\
\hline \multirow[t]{2}{*}{ History of deworming } & Yes & 93 & 45.40 & 89 (95.7) & 0.026 & 0.0408 \\
\hline & No & 112 & 54.60 & $112(100)$ & & \\
\hline
\end{tabular}


( $\leq 1$ year of age) than other categories. There was no significant difference in the prevalence of taeniid eggs between male $(72.7 \%)$ and female $(73.8 \%)$ dogs $(p>0.05)$. The production system was, however, found to be a significant factor with respect to the prevalence of taeniid $(p<0.05)$, with eggs being detected more frequently in dogs owned by pastoralists than agro-pastoralists. The prevalence rate was significantly higher in non-dewormed $(n=112,100 \%)$ compared to dewormed dogs $\left(n=89,95.7 \% ; \chi^{2}=0.0266\right.$, $P=0.04086$, Fisher exact test). At village level, Waso and Endulen had the highest proportion of dogs harbouring taeniid eggs $(80.6 \%$ and $75 \%$ respectively) compared to Malambo $(63 \%)\left(d f=2, \chi^{2}=6.5, P=0.0370\right)$.

\section{Predisposing factors for Taenia spp. infection}

\section{Disposal of animal offal and infected organs or brain}

The study found that during home slaughters $39.8 \%$ of respondents throw raw brain to dogs from clinically seen circling animals; $55.4 \%$ thrown into bush; $1.65 \%$ burned; $0.82 \%$ buried, and only $1.65 \%$ fed the brain from the animals that had died or had been slaughtered to their dogs after cooking (Table 2).

\section{Predisposing factors associated with the acquisition of Taenia spp.}

The study has also shown that predisposing factors associated with the acquisition of Taenia spp. are dogs left free all the time and some shepherd dogs (98.2\%) and a lack of worm control in dogs (93.6\%) (Table 3). At the same time, it was found that the deworming of domestic dogs was influenced by the farming system: in pastoral areas $100 \%$ of the respondents had never dewormed their dogs before, whereas only $17.9 \%$

TABLE 2: Mode of disposal of condemned brains and other infected organs from slaughtered large and small ruminants.

\begin{tabular}{lccc}
\hline Parameter & Level & $\begin{array}{c}\text { No. of respondents } \\
(\boldsymbol{n}=\mathbf{~ 1 2 1 )}\end{array}$ & $\begin{array}{c}\text { Percentage } \\
(\mathbf{\%})\end{array}$ \\
\hline Thrown raw to dog(s) & Yes & 49 & 39.80 \\
Thrown raw into bush & No & 72 & 59.50 \\
& Yes & 67 & 55.40 \\
Burned & No & 54 & 44.60 \\
& Yes & 2 & 1.65 \\
Fed to dog after cooking & No & 119 & 98.30 \\
& Yes & 2 & 1.65 \\
Buried & No & 119 & 98.30 \\
& Yes & 1 & 0.82 \\
& No & 6 & 99.20 \\
\hline
\end{tabular}

TABLE 3: Predisposing factors for Taenia spp. infection in dogs in the Ngorongoro district.

\begin{tabular}{lccc}
\hline Predisposing factors & Level & $\begin{array}{c}\text { No. of respondents } \\
(\boldsymbol{n}=\mathbf{1 1 0})\end{array}$ & $\begin{array}{c}\text { Percentage } \\
(\mathbf{\%})\end{array}$ \\
\hline Lack of worm control in & Yes & 103 & 93.6 \\
dog(s) & No & 7 & 6.4 \\
Domestic dogs & Yes & 10 & 9.1 \\
scavenging & No & 100 & 90.9 \\
Dogs left free all time & Yes & 108 & 98.2 \\
and herding & No & 2 & 1.8 \\
\hline
\end{tabular}

in agropastoral areas where veterinary services are available sometimes dewormed their dogs, although not routinely.

\section{Discussion}

The microscopic faecal examination showed that the prevalence of Taenia spp. infection was high in the study area. This finding is in agreement with the results of other researchers that Taenia spp. are common parasitic zoonotic intestinal tapeworms in dogs worldwide (Anosike et al. 2004; Davoust et al. 2008; Minnaar, Krecek \& Fourie 2002; Muhairwa et al. 2008). The overall prevalence of $73.3 \%$ of Taenia spp. eggs in the dogs in this study shows that there were frequent infections of our indigenous non-descript dogs with Taenia spp., and these species are most probably highly prevalent in the study area, reflecting the poor husbandry practices and gross lack of improvement in the country's animal health management programmes.

The high prevalence of taeniid eggs in domestic dogs indicates a high level of contamination of pastures/environment with the eggs in addition to contamination with faeces of infected wild carnivores, which was found to be highly prevalent in the area (M.B. Miran, personal communication 2015). It was found that worm control in dogs was not a common practice in the study area, with $93.6 \%$ never having dewormed their dogs. A small proportion (6.4\%) of dog owners did deworm their dogs, although not routinely.

Reports of Taenia spp. infection in some countries in Africa and other tropical to sub-tropical regions revealed a lower prevalence of taeniid eggs: $18.3 \%$ in Ethiopia (Degefu, Tefera \& Yohannes 2011), 13\% in Zambia (Nonaka et al. 2011), 9.4\% in Zaria, Nigeria (Folaranmi et al. 1984) and 2.7\% in the urban areas of Kinshasa, Zaire (now Democratic Republic of the Congo) (Schandevyl et al. 1987). The variability in the prevalence reported could be attributed to differences in the production system, the diagnostic procedures employed, the relative absence or presence of herbivore hosts, the level of immunity and husbandry practices such as the regular deworming of dogs.

Dogs less than one year old and between one and 2 years old ( $80 \%$ and $72.7 \%$, respectively) were harbouring more taeniid eggs than dogs older than $2-3$ years $(58.3 \%)$. The reasons for the lower prevalence of the eggs in this age group may be explained by the presence of an acquired immunity (Gemmell, Lawson \& Roberts 1987). There could be a number of reasons for the relatively high prevalence of taeniid eggs in one year old and younger dogs, including low immunity (Soulsby 1982).

The results obtained in this study revealed that the difference in the prevalence of taeniid eggs in male and female dogs was not statistically significant. This concurs with reports by Yacob et al. (2007) and Degefu et al. (2011) conducted in Debre Zeit and Jimma (Ethiopia), respectively.

Dogs raised in pastoral areas were significantly associated with a higher prevalence than those in agro-pastoral settings. The frequent contacts and probably a general lack of slaughter 
points in most pastoral areas could lead to dogs having wider access of infected offal or brain tissues due to the gross lack of disposal pits.

The present study employed a formalin-ether sedimentation method that is believed to be less sensitive than tests of higher sensitivities and specificities such as PCR (Christie et al. 2011; Scandrett \& Gajadhar 2004; Trachsel, Deplazes \& Mathis 2007). Based on the cross-sectional study design and test employed, the authors would anticipate lower or higher than the true prevalences of taeniid eggs. However, the observed high prevalence detected in this survey suggests that the infection rates of Taenia spp. are high in the current study areas. Since the eggs of the various Taenia spp. cannot be distinguished microscopically from one another or from those of Echinococcus spp., other diagnostic procedures should be employed (Allan et al. 2003). There is a need to develop a diagnostic method that would detect Taenia infections in dogs at species level.

At all three slaughter slabs where the study was conducted, each slab had a condemnation pit for the disposal of the unfit offal and/or carcasses. However, it was observed that these were not adequately used, especially during livestock market days, as meat inspectors do not ensure proper disposal of condemned organs. As a result, some organs or trims were simply thrown away. These pits are not fenced and they are too shallow to restrict access by scavenging dogs.

\section{Conclusion}

This study established high prevalence of taeniid eggs in dogs, which is likely to be associated with lack of knowledge regarding the predisposing factors, gross lack of helminth control measures (deworming) and high complexity of interaction between definitive hosts and feeding habits of dogs of condemned offal from intermediate hosts such as slaughtered goats and sheep. Furthermore, extensive molecular and epidemiological studies are needed to ascertain, among other things, whether there is genetic variation among Taenia spp. eggs that is microscopically indistinguishable by the screening method used. Moreover, the transmission cycle between domestic species and wildlife at the livestock-wildlife interface is not well understood. This therefore calls for additional research and improved surveillance that should lead to more appropriate control measures of the parasite and the development of a simple field diagnostic method for detecting Taenia spp. infection in both definitive and intermediate hosts. Finally, there is a need for better public awareness of the potential human health hazard posed by inadvertently ingesting Taenia eggs carried by infected domestic and wild carnivores.

\section{Acknowledgements}

The authors are grateful to Ngorongoro District and the Conservation authorities for permission to undertake this study. Pastoralists and agro-pastoralists are thanked for their co-operation and help. This study was financially supported by Inter-governmental Platform on Biodiversity and Ecosystem Service (IPBES), for which we are highly grateful. We would also like to thank the Director of Veterinary Services for their kind permission to publish this work.

\section{Competing interests}

The authors declare that they have no financial or personal relationships which may have inappropriately influenced them in writing this article.

\section{Authors' contributions}

A.A.K. made a conceptual contribution and was the project leader. E.S.S. made a conceptual contribution and was responsible for the data analysis and manuscript preparation. M.B.M. performed most of the experiments and was responsible for the manuscript preparation. J.N. performed some of the experiments.

\section{References}

Allan, J.C., Wilkins, P.P., Tsang, V.C.W. \& Craig, P.S., 2003, 'Immunodiagnostic tools for taeniasis', Acta Tropica 87, 87-93. http://dx.doi.org/10.1016/S0001-706X(03) 00059-7

Anosike, J.C., Nwoke, B.E., Ukaga, C.N., Madu, N.G. \& Dozie, I.N., 2004, 'Aspects of intestinal helminth parasites of dogs in World Bank-assisted housing estate, New Oweri, Nigeria', African Journal of Applied Zoology and Environmental Biology 6, 26-30.

Ash, R. \& Orihel, T.C., 1987, Parasites, a guide to laboratory procedures and identification, American Society of Clinical Pathologists, Denver, CO.

Christie, J., Schwan, E.V., Bodenstein, L.L., Sommerville, J.E. \& Van der Merwe, L.L. 2011, 'The sensitivity of direct faecal examination, direct faecal flotation, modified centrifugal faecal flotation and centrifugal sedimentation/flotation in the diagnosis of canine spirocercosis', Journal of the South African Veterinary Association 82(2), 71-75. http://dx.doi.org/10.4102/jsava.v82i2.37

Craig, P.S. \& Macpherson, C.N.L., 2000, 'Dogs and cestode zoonoses', in C.N.L. Macpherson, F.X. Meslin \& A.I. Wandeler (eds.), Dogs, Zoonoses and Public Health, pp. 149-211, CAB International, Wallingford.

Davoust, B., Normand, T., Bourry, O., Dang, H., Leroy, E. \& Bourdoiseau, G., 2008, 'Epidemiological survey on gastro-intestinal and blood-borne helminths of dogs in North-East Gabon', Onderstepoort Journal of Veterinary Research 75(4), 359-364. http://dx.doi.org/10.4102/ojvr.v75i4.112

Degefu, H., Tefera, A. \& Yohannes, M., 2011, 'Zoonotic helminth parasites in faecal samples of household dogs in Jimma Town, Ethiopia', Journal of Public Health and Epidemiology 3(4), 138-143.

Ernest, E., Nonga, H.E., Kassuku, A.A. \& Kazwala, R.R., 2009, 'Studies on the epidemiology of echinococcosis/hydatidosis in Ngorongoro district, Arusha region, Tanzania', Tropical Animal Health Production 41(7), 1179-1185. http://dx.doi. org/10.1007/s11250-008-9298-z

Folaranmi, D.O., Usman, S., Gimba, D. \& Okwori, J., 1984, 'Taeniid infection in dogs in Zaria Nigeria', International Journal of Zoonoses 11(2), 145-148.

Gemmell, M.A., Lawson, J.R. \& Roberts, M.G., 1987, 'Population dynamics in echinococcosis and cysticercosis - Evaluation of the biological parameters of Taenia Parasitology 94, 161-180. http://dx.doi.org/10.1017/S0031182000053543

Makene, V.M., Muhairwa, A.P., Mtambo, M.M.A., Kusiluka, L.J.M., Kambarage, D.M. \& Maeda, G.E., 1996, 'Prevalence of canine gastrointestinal parasites in Morogoro, Tanzania', Journal of Applied Animal Research 10, 149-153. http://dx.doi.org/10. Tanzania', Journal of Applied Anime
1080/09712119.1996.9706142

Martin, S.W., Meek, A.H. \& Willeberg, P., 1987, Veterinary epidemiology, principles and methods, lowa State University Press, Ames, IA.

Minnaar, W.N., Krecek, R.C. \& Fourie, L.J., 2002, 'Helminths in dogs from a peri-urban resource-limited community in Free State Province, South Africa', Parasitology 107(4), 343-349. http://dx.doi.org/10.1016/s0304-4017(02)00155-3

Miran, B.M., Nzalawahe, J., Kassuku, A.A. \& Swai, E.S., 2015, 'Prevalence of coenurosis in sheep and goats at three slaughter slab in Ngorongoro District, Tanzania', Tropical Animal Health Production 47(8), 1591-1597. http://dx.doi.org/10.1007/ s11250-015-0903-7

Muhairwa, A.P., Nonga, H.E. \& Kusiluka, L.J., 2008, 'A retrospective study of intestinal helminthosis as a cause of clinical disease in dogs', Tanzania Veterinary Journal 25 24-30. http://dx.doi.org/10.4314/tvj.v25i1.42025

Nonaka, N., Nakamura, S., Inoue, T., Oku, Y., Katakura, K., Matsumoto, J. et al., 2011 'Coprological survey of alimentary tract parasites in dogs from Zambia and evaluation of a coproantigen assay for canine echinococcosis', Annals of Tropical Medicine and Parasitology 105(7), 521-530. http://dx.doi.org/10.1179/2047773 211Y.0000000001 
Scala, A., Cancedda, G.M., Varcasia, A., Ligios, C., Garippa, G. \& Genchi, C., 2007, 'A survey of Taenia multiceps coenurosis in Sardinian sheep', Veterinary Parasitology 143, 294-298. http://dx.doi.org/10.1016/j.vetpar.2006.08.020

Scandrett, W. \& Gajadhar, A.A., 2004, 'Recovery of putative taeniid eggs from silt in water associated with an outbreak of bovine cysticercosis', Canadian Veterinary Journal 45(9), 758-760.

Schandevyl, P., Mbundu, T. \& Sumbu, W., 1987, 'Prevalence of intestinal parasite in dogs in Kinshasa, Zaire', Annales de la Societé belge de Médecine tropicale 67 369-374.

Sharma, D. \& Chauhan, P., 2006, 'Coenurosis status in Afro-Asian region: A review', Small Ruminant Research 64, 197-202. http://dx.doi.org/10.1016/j.smallrumres. 2005.05.021

Soulsby, E.J.L., 1982, Helminths, Arthropods and Protozoa of Domesticated Animals 7th edn., Baillière Tindall, London.
Swai, E.S., Kaaya, E.J., Mshanga, D.A. \& Mbise, E.W., 2010, 'A survey on gastrointestinal parasites of non-descript dogs in and around Arusha Municipality, intestinal parasites of non-descript dogs in and around Arusha Municipality,
Tanzania', International Journal of Animal and Veterinary Advance 3(2), 63-67.

Thrusfield, M., 2005, Veterinary Epidemiology, 3rd edn., Blackwell Science Ltd, London.

Trachsel, D., Deplazes, P. \& Mathis, A., 2007, 'Identification of taeniid eggs in the faeces from carnivores based on multiplex PCR using targets in mitochondrial', Parasitology 134(6), 911-920. http://dx.doi.org/10.1017/S0031182007002235

Traub, R.J., Robertson, I.D., Irwin, P.J., Mencke, N. \& Thompson, R.C., 2005, 'Canine gastrointestinal parasitic zoonoses in India', Trends in Parasitology 21, 42-48. http://dx.doi.org/10.1016/j.pt.2004.10.011

URT, 2012, Population and Housing Census, National Bureau of Statistics, Ministry of Finance, Dar-es-Salaam, Government Printer, Dar-es-Salaam.

Yacob, H.T., Ayele, T., Fikru, R. \& Basu, A., 2007, 'Gastrointestinal nematodes in dogs from Debre Zeit, Ethiopia', Veterinary Parasitology 148, 144-148. http://dx.doi org/10.1016/j.vetpar.2007.06.007 